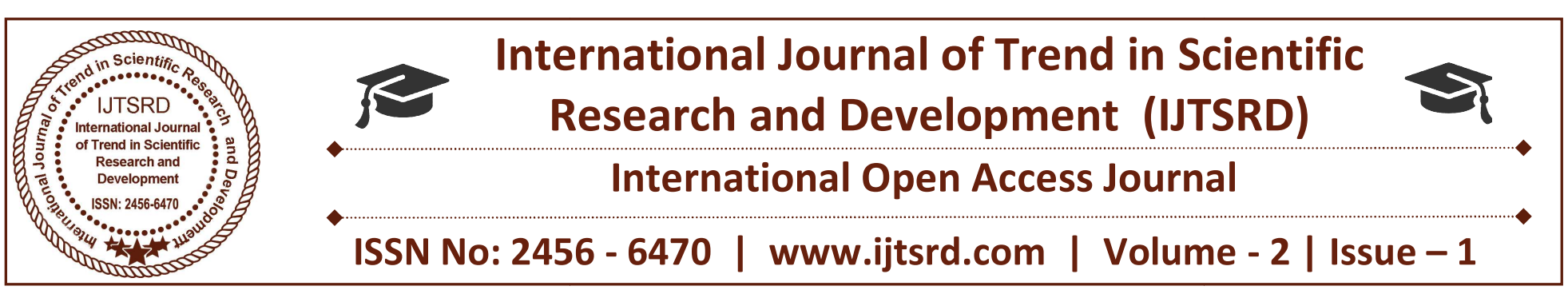

\title{
Remembering the Father of Indian Constitution - Dr. B R Ambedkar and his Role in Framing Indian Constitution
}

\author{
N. Srikanth. LLM \\ Osmania University, Hyderabad
}

\begin{abstract}
India gained the status of free and sovereign nationstate on August 15, 1947 after a long struggle and countless sacrifices. It adopted Constitution on November 26, 1949 which came in enforcement on January 26, 1950. It is often considered as one of the gigantic constitutions in the world which establishes a democratic state. The inception of the Indian Constitution in 1950 was a significant event not only in the political history of India but also in the history of social justice and human rights To write about Dr. B.R. Ambedkar's role in the making of Indian constitution is to write about the history of the debates held in the constitutional assembly.
\end{abstract}

Dr. Ambedkar wanted to give such a Constitution to India as would help establish a new social order based on the lofty principles of social, economic and political justice. Whenever any question arose about the weaker sections of the society, his heart would go out for them and he would try to secure maximum political advantage and protection for them. This was indeed natural for him because he had fought for the uplift of these sections of society during his entire political career. He never concealed this fact from anyone. In fact, he once acknowledged that he had entered the Constituent Assembly solely to protect the interests of the downtrodden people. Let us now see how some of the articles of the Constitution came to be finally framed by the Constituent Assembly. In this research paper I would like to emphasize mostly on the ambedkars role in constitutional assembly debates while framing of Indian constitution. Here, in my research paper I will point out some most important features of the Constitution, viz. the Preamble, the Fundamental Rights, directive principles, and Art-32.
Keywords: Dr. B.R Ambedkar, constitutional debates, important features of Indian constitution.

\section{INTRODUCTION}

"It might be in your interest to be our masters, but how is it in our interest to be your slaves?

- Abraham Lincoln

India gained the status of free 'and sovereign "nationstate on August 15, 1947 after a long struggle and countless sacrifices. It adopted constitution on November 26, 1949 which came in enforcement on January 26, 1950. It is often considered as one of the gigantic constitutions in the world which establishes a democratic state. The inception of the Indian Constitution in 1950 was a significant event not only in the political history of India but also in the history of social justice 'and human rights'.

To write about Dr. B.R. Ambedkar's role in the making of Indian constitution is to write about the history of the debates held in the constitutional assembly. Dr. Ambedkar, before being elected as Chairman of the Drafting Committee, had functioned as a Member of the Advisory Committee on Minorities and Fundamental Rights and its two Sub-Committees, and the Union Constitution Committee. He was also a Member of the Committee on the Functions of the Constituent Assembly under the Indian Independence Act, 1947. The other important Committees directly related to Constitution-making were the Provincial Constitution Committee, the Union Powers Committee, the Expert Committee on Financial Provisions, and the Sub-Committee on Tribal Areas. There was also a 
Commission on the question of creation of linguistic provinces appointed on the recommendation of the Drafting Committee. The reports of these several Committees received Dr. Ambedkar's close scrutiny and attention, both when they came for discussion in the Constituent Assembly and in his capacity as Chairman of the Drafting Committee.

\section{The early life and education of Dr. B.R Ambedkar, how he became a leader of untouchables}

Before start about his early life it is very important to know about the then social status of untouchables. Who are the untouchables? They occupy the lowest rank of the Hindu Caste system and thereby the fateful destiny of being regarded as the "outcaste" by the top three castes. They come to referred to as the untouchables since their very touch-not just physical but "shadow and even voice"-was considered polluting for caste Hindus. Ambedkar's biographer Dhananjay Keer provides a vivid description of the social disabilities forced on the untouchables by the Hindu caste system.

They were forbidden to keep certain animals, to use certain metals for ornaments, were obliged to wear a particular type of dress, to eat a particular type of food, to use a particular type of footwear and were forced to occupy the dirty, dingy and unhygienic outskirts of villages and town for habitation where they lived in dark, insanitary and miserably smoky shanties or cottages. Since their very touch was polluting, they were denied the use of public wells, often public roads and their children were not allowed into public schools for caste Hindu children. "These untouchable Hindus were treated by the caste Hindus as sub-humans, less than men, worse than beasts".

In such a social climate of hatred, oppression and exclusion, Ambedkar was born to a Mahar family originally hailing from konkan. His ancestral village, Ambavade was situated in the Ratnagiri district of Maharastra in 1891. A Marathi, the local language, proverb characterizes the mahar as eaters "of forbidden food".

Being born to a middle class family, Ambedkar was educated in the local school and, in spite of suffuring "life-defining humiliation" during his formative years, went on to become the first college graduate in the mahar community when he graduate from the prestigious Elphinstone college in Bombay. His incredible intellectual abilities and promise and academics achievements earned him the financial support from the Maharaja of Baroda, Sayyajirao
Gaikwa, for his stay at Columbia University where he earned a PhD in Economics. Even urging his education at Columbia this gifted and innovative son of Mahar and india stayed focused on understanding the sociopolitical underpinnings of the caste system and changing the plight of his community -the untouchables who were marginalized in every aspect of communal life.

In his very first speech in the Constituent Assembly on December 17, 1946, much before he became Chairman of the Drafting Committee, Dr. Ambedkar gave expression to his firm faith in a united India.' (He was participating in the debate on the historic Objectives Resolution moved by Jawaharlal Nehru.) He said:

I have got not the slightest doubt in my mind as to the future evolution and the ultimate shape of the social, political and economic structure of this great country. I know today we are divided politically, socially and economically. We are a group of warring camps and I may go even to the extent of confessing that I am probably one 'of the leaders of such a camp. But, Sir, with all this I am quite convinced that given time and circumstances, nothing in the world will prevent this country from becoming one: With all our castes and creeds, I have not the slightest hesitation that we shall in some form be a united people.

Dr. Ambedkar wanted to give such a Constitution to India as would help establish a new social order based on the lofty principles of social, economic and political justice. Whenever any question arose about the weaker sections of the society, his heart would go out for them and he would try to secure maximum political advantage and protection for them. This was indeed natural for him because he had fought for the uplift of these sections of society during his entire political career. He never concealed this fact from anyone. In fact, he once acknowledged that he had entered the Constituent Assembly solely to protect the interests of the downtrodden people when he said:

"I came into the Constituent Assembly with no greater aspiration than to safeguard the interests of the Scheduled Castes. I had not the remotest idea that I would be ca lied upon to undertake more responsible functions. I was, therefore, greatly surprised when the Assembly elected me to the Drafting Committee. I was more than surprised when the Drafting Committee elected me to be its Chairman. There were in the Drafting Committee men bigger, better and more competent than myself such as my friend Sir Alladi 
Krishnaswami Ayyar. I am grateful to the Constituent Assembly and the Drafting Committee for reposing in me so much trust and confidence and to have chosen me as their instrument and given me this opportunity of serving the country"

\section{Constitution of drafting committee}

On 29 August 1947, the names of the Members of the Drafting Committee were announced in the Constituent Assembly. It was headed by Dr. B.R. Ambedkar and included such legal luminaries as Alladi Krishnaswami Ayyar, N. Gopalaswami Ayyangar, K.M. Munshl, Saiyid Mohd. Saadulla, B.L. Mitter and D.P. Khaitan. The Drafting Committee was subsequently reconstituted when N. Madhava Rao was appointed to replace B.L. Mitter, and T.T. Krishnamachan to fill the vacancy caused by the death of D.P. Khaitan. In the great task of the framing of the Constitution, Dr. Ambedkar s association was close at all levels. He took keen interest in the framing of the Rules of Procedure of the Constituent Assembly which helped in conducting its business on sound parliamentary principles. The President and the other Members of the Constituent Assembly looked to him for guidance whenever there was any procedural wrangle or when any Member had posed a difficult constitutional conundrum which required immediate answer. The Draft Constitution was introduced by Dr. Ambedkar for the consideration of the Assembly on 4 November 1948. When this Draft was being debated in the Assembly, Dr. Ambedkar, as the Chairman of the Drafting Committee, had to answer many points raised by the Members. Being a man of vast political experience, he spoke with authority and was heard with rapt attention by the Members of the Assembly. He spoke elaborately on the various provisions made in the Draft and on the various amendments moved by the Members. He was always ready to answer points raised by the Members.

Dr. Ambedkar had a clear perception of the mutuality of the three pillars of State-the legislature, the executive, and the judiciary. He realised that the jurisdiction of each should be clear and untrammeled.
At the same time, he had a sense of the limitations of these three pillars of democracy and of the importance of the role of citizen.

The following observation he made is significant:

The Constitution is a fundamental document. It is a document which defines the position and power of the three organs of the State-the executive, the .Judiciary and the legislature. It also defines the powers of the executive and the powers of the legislature as against the citizens, as we have done in our chapter dealing with Fundamental Rights. In fact, the purpose of a Constitution is not merely to create the organs of the State but to limit their authority, because, if no limitation was Imposed upon the authority of the organs, there will be complete tyranny and complete oppression.

Let us now see how some of the articles of the Constitution came to be finally framed by the Constituent Assembly. The following most important features of the Constitution, i.e., the Fundamental Rights, directive principles, and Art-32

\section{Fundamental rights}

The basic plan of the Fundamental Rights guaranteed in the Constitution was prepared by the Advisory Committee on Fundamental Rights. A number of memoranda were submitted to this Committee by eminent Members like K.M. Munshi, K.T. Shah and others, but the Fundamental Rights, as finally adopted by the Constituent Assembly, are far more proximate to the suggestions of Dr. Ambedkar than to the suggestions of any other Member of the Assembly.

A close look at Art. II Sec. I of his Memorandum" and the Constitution reveals that, of the 19 articles dealing with the Fundamental Rights, as many as 15 articles can be traced to the suggestions put forward by Dr. Ambedkar. To make the position clear, here is a comparative statement: 
International Journal of Trend in Scientific Research and Development (IJTSRD) ISSN: 2456-6470

\begin{tabular}{|c|c|c|c|}
\hline $\begin{array}{l}\text { Sr } \\
\text { No }\end{array}$ & Subject & $\begin{array}{l}\text { Article of the } \\
\text { Constitution }\end{array}$ & $\begin{array}{l}\text { Clauses of Articles II } \\
\text { sec. } 1 \text { of the } \\
\text { memorandum }\end{array}$ \\
\hline 1 & Equality before law & 14 &  \\
\hline 2 & Prohibition of discrimination & 15 & $4 \& 5$ \\
\hline 3 & Equality of opportunity & 16 & 6 \\
\hline 4 & Abolition of untouchability & 17 & 1 \\
\hline 5 & Right to freedom & 19 & $7 \& 12$ \\
\hline 6 & Protection in respect of conviction for Offences & 20 & 13 \\
\hline 7 & Protection of life and personal liberty & 21 & 2 \\
\hline 8 & Protection against arrest and detention & 22 & 2 \\
\hline 9 & Prohibition of traffic in human beings and Force labour & 23 & 9 \\
\hline 10 & Prohibition of employment of children in factories & 24 & 9 \\
\hline 11 & $\begin{array}{l}\text { Freedom of consciences and free Profession, Practice and } \\
\text { propagation of religion }\end{array}$ & 25 & 14 \\
\hline 12 & Freedom to manage religious affairs $18 \& 19$ & 26 & \\
\hline 13 & $\begin{array}{l}\text { Freedom as to payment any taxes for Promotion of any } \\
\text { particular religion }\end{array}$ & 27 & 20 \\
\hline 14 & $\begin{array}{l}\text { Freedom as to attendance at religious Instruction or religious } \\
\text { worship in certain Educational institutions }\end{array}$ & 28 & 15 \\
\hline 15 & Remedies for enforcement of fundamental Rights & 32 & 21 and $\mathrm{CI}(1)$ of sec. II \\
\hline
\end{tabular}

The remaining four articles which did not find place in Dr. Ambedkar's Memorandum relate to: Abolition of titles (Art. 18); Cultural and educational rights of minorities (Arts. 29 and 30); and Right to property (Art. $31)$.

The Discussion on the Fundamental Rights began in the Constituent Assembly on 25th November 1948. Replying to the critics of the wide definition of the word 'State' used in draft Art. 7, which later became Art. 12 of the Constitution, Dr. Ambedkar emphasized the two-fold objectives of the Fundamental Rights and their universal application.

The object of the Fundamental Rights is two-fold. First, that every citizen must be in a position to claim those rights. Secondly, they must be binding upon every authority-I shall presently explain what the word "authority" means--upon every authority which has got either the power to make laws or the power to have discretion vested in it. Therefore, it is quite clear that if the Fundamental Right. are to be clear, then they must be binding not only upon the Central Government, they must not only be binding upon the Provincial
Government, they must not only be binding upon the governments established in the Indian states, they must also be binding upon district local boards , Municipalities, even village panchayats and taluka boards, in fact, every authority which has been created by law and which has got certain power to make laws, to make rules, or make by-laws'

Draft Art. 13 guaranteeing the seven freedoms were as follows :(1) Subject to the other provisions of this article: all citizens shall have the right:

a. to freedom of speech and expression

b. to assemble peaceably and without arms

c. to form associations or unions

d. to move freely throughout the territory of India

e. to reside and settle in any part of the territory of India

f. to acquire, hold and dispose of property; and

g. to practice any profession, or to carry on any occupation, trade or business. 
These were not an absolute rights, it was followed by certain restrictions. Under Draft article 13(1-6) When the Draft Constitution was circulated for public opinion, the provisions relating to this article received, By far, the most critical comments from some sections of the society. Fully conscious of the importance of these provisions, Dr. Ambedkar, while introducing the Draft Constitution on 4 November 1948, replied to the critics in these words

The most criticized part of Draft Constitution is that which relates to fundamental rights. It is said that Article 13' which defines fundamental rights is riddled with so many exceptions that the exceptions have eaten up the rights altogether. It is condemned as a kind of deception. In the opinion of the critics fundamental rights are not fundamental rights unless they are also absolute rights. The critics rely on the Constitution of the United States and on the Bill of Rights embodied in the first ten Amendments to that Constitution in support of their contention. It is said that the fundamental rights in the American Bill of Rights are real because they are not subjected to limitations or exceptions. I am sorry to say that the whole of the criticism about fundamental rights is based upon a misconception. In the first place, the criticism in so far as it seeks to distinguish fundamental rights from non-fundamental rights is not sound. It is incorrect to say that fundamental rights are absolute while non-fundamental rights are not absolute. The real distinction between the two is that no fundamental rights are created by agreement between parties while fundamental rights are the gift of the law. Because fundamental rights are the gift of the State, it does not follow that the State cannot qualify them.

When this article came up for discussion in the Assembly, over a hundred amendments were proposed. Of these, only three were accepted by Dr. Ambedkar.

\section{Directive principle of state polices}

If Chapter Three of the Constitution on Fundamental Rights provides for the political and civil rights of individuals, Chapter Four enshrines Directive Principles of State Policy which deal with the concept of socio-economic justice. Directive Principles, which are given in the Constitution immediately after the Fundamental Rights, 10 fact, complement the latter. They aim at directing the State to ensure social and economic justice to individuals. Needless to say, the Directive Principles present a novel feature of the Indian Constitution.The only other Constitution of a parliamentary democracy which embodies these principles is that of Ireland. The Directive Principles were criticized by Members of the Constituent Assembly. They described them as "only pious declarations having no binding force". All this criticism was found to be superfluous by Dr. Ambedkar because the Constitution itself had declared them to have no binding force. Answering the charge Dr. Ambedkar said:

If it is said that the Directive Principles have no legal force behind them, I am prepared to admit it. But I am not prepared to admit that they have no sort of binding force at all. Nor am I prepared to concede that they are useless because they have no binding force. The Directive Principles are like the Instrument of Instructions which were issued to the GovernorGeneral and to the Governors of the Colonies and to those of India by the British Government under the 1935 Act. Under the Draft Constitution it is proposed to Issue such instruments to the President and to the Governors. The texts of these Instruments of Instructions will be found in Schedule IV of the Constitution. What is called Directive Principles is merely another name for Instruments of Instructions. The only difference is that they are instructions to the Legislature and the Executive. Such a thing is to my mind to be welcomed. Wherever there is a grant of power in general terms for peace, order and good government, it is necessary that it should be accompanied by instructions regulating its exercise.

Inclusion of Directive Principles in the Constitution was further justified by Dr. Ambedkar on the ground that being a democratic country, in India it would be the people who would be electing their Government. Whoever came to power would not be free to do what he liked because of the existence of Directive .Principles. In the exercise of power he would be respecting these Instruments of Instructions. While a Government might not have to answer for the breach of the Directive Principles in a Court of Law, it certainly would have to answer for them before the electorate during the elections.

\section{Article 32}

The Fundamental Rights enshrined in the Constitution of India have been made justifiable. Article 32(2) states: "the Supreme Court shall have power to issue directions or orders or writs, including writs in the shape of habeas corpus, mandamus, prohibition, quo warranto and certiorari whichever may be appropriate, for the enforcement of any of the rights 'conferred by 
this Part". The provision of this constitutional remedy, which follows almost hterally the provision suggested by Dr. Ambedkar in Cl. (1) of Sec. II, Art. II of his Memorandum is the most effective guarantee for enforcing the Fundamental Rights. But for this provision, the insertion of Fundamental Rights in the Constitution would have been meaningless as rights are real only if they are accompanied by remedies. Dr. Ambedkar described the importance of Art. 32 in these terms on the floor of the House:

I am very glad that the majority of those who spoke on this article have realized the importance and significance of this article. If I was asked to name any particular article in this Constitution as the most important-an article without which this Constitution would be a nullity

I could not refer to any other article except this one. It is the very soul of the Constitution and the very heart of it and I am glad that the House has realized its importance.

On 17 November 1949, the Constituent Assembly began the third reading of the Constitution Bill. Dr. Ambedkar replied to the nine-day debate in the afternoon of 25 November 1949. Speaking with a feeling of great relief, he gave a graphic picture of the work done by the Drafting Committee and the Assembly. He also thanked the Assembly for having given him an opportunity for serving the county. Then Dr. Ambedkar turned his thoughts to the future of the country and expressed his anxiety in these words:

Here I could have ended. But my mind is so full of the future of our' country that I feel I ought to. Take this occasion to give expression to some of my reflections thereon. On 26 January 1950, India will be an independent country. What would happen to her, independence will she maintain her independence or will she lose it again? This is the first thought that comes to my mind. It is not that India was never an independent country. The point is that she once lost the independence she had. Will she lose it a second time? It is this thought which makes me most anxious for the 'future. What perturbs me greatly' is the fact that not only India has once before lost her independence but she lost it by the infidelity and treachery of some of her own people. In the invasion of Sind by Mohammed-BinKasim, the military commanders of King Dahar accepted bribes from the agents of Mohammed-BinKasimand refused to fight on the side of their King. It was Jaichand who invited Mahommed Gohri to invade India and fight against Prithvi Raj and promised him the help of himself and the Solanki Kings. When Shivaji was fighting for the liberation of Hindus, the other Maratha noblemen and the Rajput Kings were fighting the battle on the side of Moghul Emperors. When the British were trying to destroy the Sikh Rulers, Gulab Singh, their principal commander, sat silent and did not help to save the Sikh kingdom. .Will history repeats itself? It is this thought which fills me with anxiety. This anxiety is deepened by the realization of the fact that in addition to our old, enemies in the form of castes and creeds we are going to have many political parties with diverse and opposing political creeds. Will Indians place the country above their creed or will they place creed above country? I do not know. But this much is certain that if the parties place creed above country, our independence will be put in jeopardy a second time and probably is lost forever. This eventuality we must all resolutely guard against. We must be determined to defend our independence with the last drop of our blood.

He further said:

On 26 January 1950, India would be a democratic country in the sense that India from that day would have a "government of the people, by the people and for the people". The same thought comes to my mind. What would happen to her democratic Constitution? Will she be able to maintain it or will she lose it again? This is the second thought that comes to my mind and makes me as anxious as the first.

\section{Conclusion}

To produce the Constitution, with its 395 articles and 8 schedules, the Constituent Assembly sat for 165 days in 11 sessions, out of which 114 days, spread over five sessions, were devoted to the finalization of the Draft Constitution introduced by Dr. Ambedkar on 4 November 1948. The proceedings of the last five sessions of the Constituent Assembly are printed in five volumes (Vol. VII-X1) and cover more than 4600pages. How minutely the Draft Constitution was scrutinized by the Members of the Assembly is evident from the large number of amendments to which they had given notice. As many as 7,635 amendments were tabled and 2,473 were actually moved in the House, the rest being withdrawn after some discussion. A study of the voluminous debates reveals that Dr. Ambedkar, the chief architect of the Constitution, was closely questioned on each and every provision being made in the Constitution, and he was always found ready to answer all sorts of doubts and quires of the Members. Though a good number of the amendments moved by 
the Members were accepted by the Constituent Assembly, no amendment was accepted by the House unless it was acceptable to Dr. Ambedkar. Dr. Rajendra Prasad, President of the Constituent Assembly, paid glowing tributes to Dr. Ambedkar for his zeal and devotion in helping the Assembly to accomplish the Herculean task of framing a worthy Constitution for free India's governance.

In Dr. Rajendra Prasad's own words:

Sitting in the Chair and watching the proceedings from day to day, I have realized as nobody else could have, with what zeal and devotion the members of the Drafting Committee, and especially its Chairman, Dr. Ambedkar, in spite of his indifferent health, have walked. We would never make a decision which was or could be ever so right as when we put him on the Drafting Committee and made him its Chairman. He has not only justified his selection but has added luster to the work which he has done.

\section{References}

1) Anil Bharadwaj (2002) Welfare of Scheduled Castes in India: Gandhi's Social Approach; Ambaedkar's Political Approach; Constitutional Safeguards and Schemes for Welfare of Scheduled Castes, New Delhi: Deep \& Deep. Publication.

2) Dr B R Ambedkar: The Messiah of the Downtrodden Hardcover - 1 Jan 2010

a. By Janak Singh, Kalpaz Publications (1 January 2010)

3) Constitutional Assembly Debate, 17 December 1946, p. 100.

4) CAD, 4 November 1948, p. 44.

5) CAD, 17 October 1949, pp. 455-456.

6) CAD, 25 November 1948, p. 610.

7) CAD, 4 November 1948, p. 40.

8) CAD, 9 December 1948, p. 953.

9) CAD, 25 November 1949, pp. 977-978.

10) Ibid.pp. 980-981.

11) CAD, 26 November 1949, p. 995.

12) Ibid. p. 994. CAD, 17 December 1946, p. 100. 